A VELVET EMPIRE 


\section{HISTORIES OF ECONOMIC LIFE}

\section{Jeremy Adelman, Sunil Amrith,}

Emma Rothschild, and Francesca Trivellato, Series Editors

A Velvet Empire: French Informal Imperialism in the Nineteenth Century by David Todd

Making It Count: Statistics and Statecraft in the Early People's Republic of China by Arunabh Ghosh

Empires of Vice: The Rise of Opium Prohibition across Southeast Asia by Diana S. Kim

Pirates and Publishers: A Social History of Copyright in Modern China by Fei-Hsien Wang

Sorting Out the Mixed Economy: The Rise and Fall of Welfare and Developmental States in the Americas by Amy C. Offner

Red Meat Republic: A Hoof-to-Table History of How Beef Changed America by Joshua Specht

The Promise and Peril of Credit: What a Forgotten Legend about Jews and Finance Tells Us about the Making of European Commercial Society by Francesca Trivellato

A People's Constitution: The Everyday Life of Law in the Indian Republic by Rohit De

A Local History of Global Capital: Jute and Peasant Life in the Bengal Delta by Tariq Omar Ali 


\section{A Velvet Empire}

FRENCH INFORMAL IMPERIALISM IN

THE NINETEENTH CENTURY

DAVID TODD

PRINCETON UNIVERSITY PRESS

PRINCETON \& OXFORD 
Copyright (C) 2021 by Princeton University Press

Requests for permission to reproduce material from this work should be sent to permissions@press.princeton.edu

Published by Princeton University Press

41 William Street, Princeton, New Jersey o8540

6 Oxford Street, Woodstock, Oxfordshire OX20 1TR

press.princeton.edu

All Rights Reserved

Library of Congress Cataloging-in-Publication Data

Names: Todd, David, 1978- author.

Title: A velvet empire : French informal imperialism in the nineteenth century /

David Todd.

Description: Princeton ; Oxford : Princeton University Press, [2021] |

Series: Histories of economic life | Includes bibliographical references and index.

Identifiers: LCCN 2020022660 (print) | LCCN 2020022661 (ebook) | ISBN 9780691171838 (hardback) | ISBN 9780691205342 (ebook)

Subjects: LCSH: France-Foreign relations-19th century. | France-Politics and government—19th century. | France-Colonies-History-19th century. |

France-Foreign economic relations - 19th century. |

France-Commerce-History-19th century.

Classification: LCC DC252 .T63 2021 (print) | LCC DC252 (ebook) |

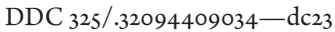

LC record available at https://lccn.loc.gov/202002266o

LC ebook record available at https://lccn.loc.gov/2020022661

British Library Cataloging-in-Publication Data is available

Editorial: Eric Crahan, Priya Nelson, and Thalia Leaf

Production Editorial: Natalie Baan

Jacket Design: Karl Spurzem

Production: Jacquie Poirier

Publicity: Kate Farquhar-Thomson and Alyssa Sanford

Jacket art: (top) Shutterstock; (bottom) Opening of the Suez Canal on Nov. 17, 1869. At the invitation of the Khedive Ismail, the French empress Eugénie's imperial yacht led the procession of ships opening the canal. 1869 engraving with 2011 color /

Everett Collection Inc. / Alamy Stock Photo

This book has been composed in Arno

Printed on acid-free paper. $\infty$

Printed in the United States of America

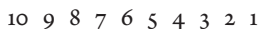


For my mother 
